\title{
Resveratrol, Potential Therapeutic Interest in Joint Disorders: A Critical Narrative Review
}

\author{
Christelle Nguyen ${ }^{1,2,3, *}$, Jean-François Savouret ${ }^{1,2}$, Magdalena Widerak ${ }^{1,2}$, \\ Marie-Thérèse Corvol ${ }^{1,2}$ and François Rannou ${ }^{1,2,3}$ \\ 1 Université Paris Descartes, Sorbonne Paris Cité, Paris 75006, France; \\ jean-francois.savouret@parisdescartes.fr (J.-F.S.); marie-therese.corvol@parisdescartes.fr (M.-T.C.); \\ francois.rannou@aphp.fr (F.R.) \\ 2 INSERM UMR 1124, Faculté des Sciences Fondamentales et Biomédicales, Laboratoire de Pharmacologie, \\ Toxicologie et Signalisation Cellulaire, UFR Biomédicale des Saints Pères, Paris 75006, France \\ 3 Service de Rééducation et de Réadaptation de l'Appareil Locomoteur et des Pathologies du Rachis, \\ Hôpitaux Universitaires-Paris Centre, Groupe Hospitalier Cochin, Assistance Publique-Hôpitaux de Paris, \\ Paris 75014, France \\ * Correspondence: christelle.nguyen2@aphp.fr; Tel.: +33-158-412-945
}

Received: 29 November 2016; Accepted: 4 January 2017; Published: 6 January 2017

\begin{abstract}
Trans-resveratrol (t-Res) is a natural compound of a family of hydroxystilbenes found in a variety of spermatophyte plants. Because of its effects on lipids and arachidonic acid metabolisms, and its antioxidant activity, t-Res is considered as the major cardioprotective component of red wine, leading to the "French Paradox" health concept. In the past decade, research on the effects of resveratrol on human health has developed considerably in diverse fields such as cancer, neurodegenerative and cardiovascular diseases, and metabolic disorders. In the field of rheumatic disorders, in vitro evidence suggest anti-inflammatory, anti-catabolic, anti-apoptotic and anti-oxidative properties of $\mathrm{t}$-Res in various articular cell types, including chondrocytes and synoviocytes, along with immunomodulation properties on $\mathrm{T}$ and $\mathrm{B}$ lymphocytes. In preclinical models of osteoarthritis and rheumatoid arthritis, resveratrol has shown joint protective effects, mainly mediated by decreased production of pro-inflammatory and pro-degradative soluble factors, and modulation of cellular and humoral responses. Herein, we comprehensively reviewed evidence supporting a potential therapeutic interest of t-Res in treating symptoms related to rheumatic disorders.
\end{abstract}

Keywords: trans-resveratrol; chondrocyte; synoviocytes; aryl hydrocarbon receptor; inflammation; pain; osteoarthritis; rheumatoid arthritis

\section{Introduction}

Mediterranean societies have developed the "Mediterranean diet" under the influence of Greek medicine. This diet consists of a moderate intake of animal meat and fat in combination with high consumption of vegetables, fruits and olive oil. Natural antioxidants, fibers, B vitamins and unsaturated fatty acids are also present with red wine as the essential alcoholic beverage, consumed with meals on a daily basis [1]. The beneficial effect of this diet upon coronary heart disease prevention has been a matter of debate, recently refueled by the controversy over the "French Paradox". This concept arose from studies showing the low rate of coronary heart disease in wine-drinking French population compared to other Western populations, despite the presence of elevated risk factors including high animal fat intake, low exercise level, and heavy smoking [2]. This controversy started on epidemiological grounds, further fueled by negative experimental data [3], and eventually led to the speculation that red wine may contain cardioprotective compounds, especially antioxidant polyphenols. 
Indeed, red wine contains several polyphenols including phenolic acids, hydroxystilbenes and flavonoids. Trans-resveratrol (3,5,4'-trihydroxystilbene, $t$-Res) is the parent compound of a family of hydroxystilbenes existing in cis- and trans-configurations in a variety of spermatophyte plants such as grapevine, peanuts, pine or Chinese knotweed [3]. Because of its effects on lipids and arachidonic acid metabolisms, and its antioxidant activity, t-Res was considered the major cardioprotective component of red wine. In grapes, $\mathrm{t}$-Res is produced as an antifungal phytoalexin in response to infection by Bothrytis cinerea. $\mathrm{t}$-Res is present in red wine in concentrations ranging from 0.1 to $14.5 \mathrm{mg} / \mathrm{L}$ [4]. Several Asian pharmacopoeas describe Chinese knotweed (Polygonum cuspidatum) powder as an anti-inflammatory drug, used in various conditions such as pain, fever, dermatitis, atherosclerosis, hyperlipemia and cancers [5]. Experimental and clinical data suggest that t-Res anti-inflammatory and analgesic effects may be of clinical interest as a complementary treatment in joint diseases $[4,6]$. Hypotheses about resveratrol mechanisms of action suggest a modulation of endocrine disruption, apoptosis and oxidative stress. Herein, we reviewed evidence supporting a potential therapeutic interest of $\mathrm{t}$-Res in treating symptoms related to rheumatic disorders. The process of article selection was unsystematic and based on authors' expertise, self-knowledge, and reflective practice.

\section{Literature Review}

\subsection{Molecular Targets of Resveratrol}

Pharmacological properties of $\mathrm{t}$-Res in various models have been extensively described in the literature [6-12]. The hypothesized beneficial properties of $t$-Res include detoxification through antagonization of the aryl hydrocarbon and dioxin receptor (AhR), kinases inhibition, anti-inflammatory, analgesic and anti-tumoral activities. These effects underlie the reported protective effects of t-Res in carcinogenesis, cardiovascular and neurodegenerative diseases, as well as its metabolic effects on glucose homeostasis (Figure 1).

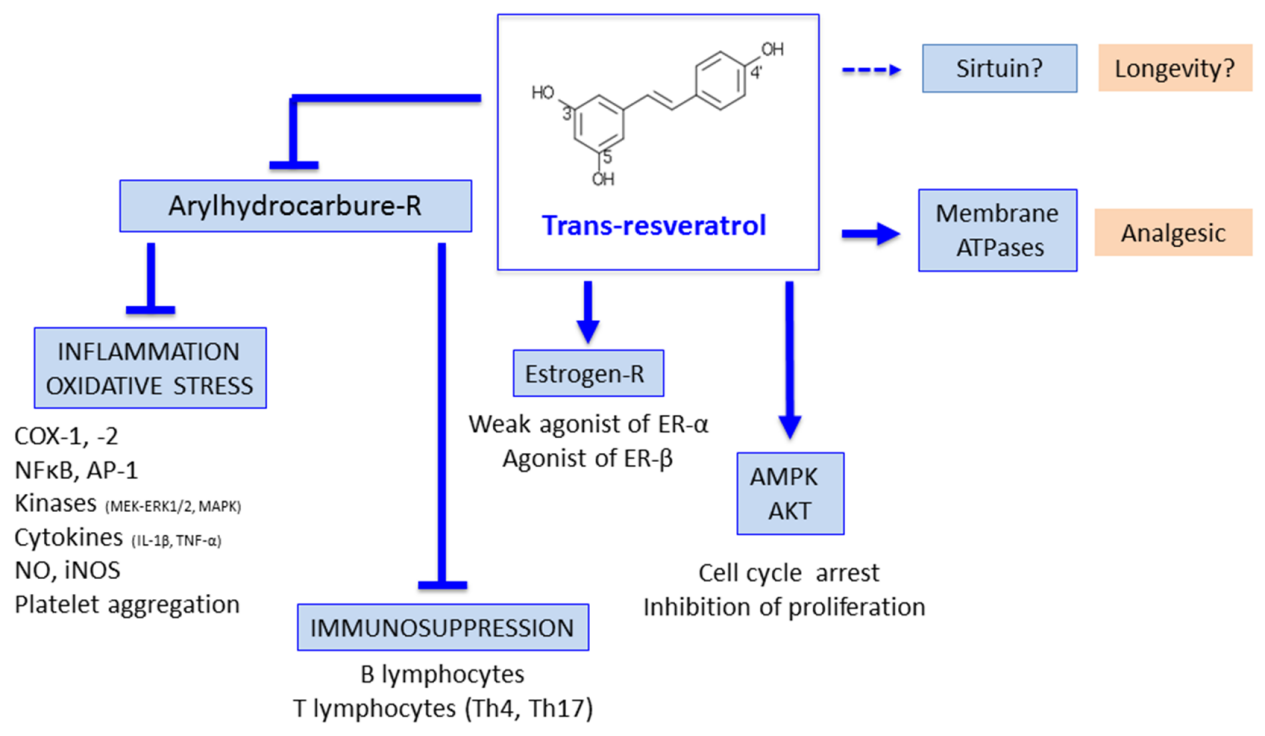

Cardioprotector, neuroprotector, anti-cancer, anti-osteoporosis

Figure 1. The pleiotropic effects of $t$-Resveratrol (t-Res). AKT: Protein kinase B; AMPK: 5' adenosine monophosphate-activated protein kinase; AP-1: Activator protein 1; COX: cyclooxygenase; ER: estrogen receptor; ERK1/2: Extracellular signal-regulated protein kinases 1 and 2; IL-1 $\beta$ : Interleukin-1 $\beta$; MAPK: Mitogen-activated protein kinase; MEK: Mitogen-activated protein kinase kinase; NFKB: nuclear factor kappa-light-chain-enhancer of activated B cells; R: receptor; Th: T helper; TNF- $\alpha$ : Tumour necrosis factor- $\alpha$. 
Initial reports showed that $\mathrm{t}$-Res anti-inflammatory activities, in acute and chronic phases of inflammation, were related to its ability to modulate cyclooxygenase (COX)-1 and $-2[5,13]$. The first target identified at the molecular level was the AhR [14]. Aryl hydrocarbons and dioxins are found in smoke, exhaust and industrial fumes. AhR activation promotes endocrine disruption, oxidative stress, inflammation, apoptosis and immunosuppression, and is associated with an increased risk of diabetes, osteoporosis and cancers. $t$-Res is a strong $\mathrm{AhR}$ competitive antagonist $\left(\mathrm{IC}_{50} 6 \mu \mathrm{M}\right)$ and is able to inhibit effects related to AhR activation [14]. As a stilbene, $t-R e s$ is a modulator of membrane ATPases [15], which is associated to its analgesic effects. As a polyphenol, t-Res is a weak agonist of the Estrogen Receptor (ER)- $\alpha$, and an agonist of ER- $\beta$ [16], a property relevant to its bone protecting effects. AhR antagonists based on the structure of $t$-Res, but devoid of any interaction with the ER, have been designed by our group [17]. As a polyphenol, $t$-Res is also a tyrosine kinases inhibitor ( $\mathrm{IC}_{50} 10-25 \mu \mathrm{M}$ ), and a modulator of the MEK-ERK1/2, MAPK, AP-1 and NF- $\mathrm{KB}$ pathways in various tissues [18-21]. $\mathrm{t}$-Res can inhibit chemical induction of pre-neoplastic lesions in mice. $\mathrm{t}$-Res was proposed to act through the inhibition of COX and hydroperoxidase enzymes, by the induction of phase 2 drug-metabolizing enzymes, by its anti-oxidant activity, and by the induction of cancer cells to differentiate [22]. Cell cycle and apoptosis can also be modulated by t-Res $[23,24]$. More recently, the physiological role of $\mathrm{AhR}$ as a regulator of immune innate and adaptive responses has been evidenced [25]. The disruption of AhR leads to impaired development of immune organs and functions [26,27]. Activation of AhR by a particular ligand can induce a wide range of biological responses in Treg, Th17 and B lymphocytes, both under dioxins and $\mathrm{t}$-Res influence [28,29]. This may mimic a physiological role, elicited by unknown physiological ligands.

Finally, the sirtuin (Sirt)-1 controversy has to be mentioned. A link between t-Res and Sirt-1 activation leading to cardiac function improvement in animal models of diabetic cardiomyopathy has been suggested [30]. However, whether these findings can be translated to other cardiovascular conditions remains controversial. So far, the life-expanding ability of resveratrol is limited to yeast, invertebrates and mice. Yet, mice do not live longer under resveratrol or sirtuin activator treatment, unless fed a high-fat diet. Mice diverge from humans in terms of cancer and aging. They bear an active telomerase and they never achieve "skeletal" puberty as their cartilage grows until death. Mice harbour an extremely sensitive AhR due to their lack of its endogenous negative modulator 7-keto-cholesterol [31]. In addition, the C57Bl6 mouse strain harbours an abnormal AhR with a Kd for dioxins at $6.5 \mathrm{pM}$, compared to the usual 2 to $5 \mathrm{nM}$ of most mammals [32]. Could this "super" AhR produce sirtuins activators through enhanced oxidative metabolism? To date, there is no clear direct link between resveratrol and sirtuins. The addition of $5^{\prime}$ adenosine monophosphate-activated protein kinase (AMPK) and peroxisome proliferator-activated receptor gamma coactivator (PGC)-1 in the picture might be interpreted as a drift towards the promotion of pharmaceutical drugs [33]. The doses used in vivo by Park and colleagues are 150-fold (intraperitoneally) and 3000-fold (per os) the fully active dose of $40 \mathrm{mg} /$ day, when t-Res is used in the proper galenic form [34]. The doses used in Park and colleagues' paper are in the range of $50 \mu \mathrm{M}$ that is able to activate the ER [16] (personal data). Estradiol effects include AMPK and PGC-1 induction [35,36]. Furthermore, concerns have been raised about the recurrent trend to amalgamate resveratrol, sirtuins, calorie restriction, aging diseases and aging itself, despite righteous claims that aging is not a disease [37].

\subsection{The Problem with Bioavailability}

Animal and human studies concur on the poor bioavailability of $\mathrm{t}$-Res through low uptake and extensive metabolization, notably by sulfatation and glucuronidation. This poor bioavailability is clearly a major barrier for human use. In humans and rats, t-Res rapidly undergoes conjugation resulting in one percent of the oral dose being observed as free $t$-Res in blood plasma [38-41]. t-Res efficiency depends on a sufficient level of active molecule in bloodstream and target tissues.

In in vitro and in vivo models, active concentrations of $\mathrm{t}$-Res range from 1 to $25 \mu \mathrm{M}[14,42,43]$. Therefore, the development of nutritional and therapeutic application of $t$-Res has been greatly limited 
by its poor bioavailability. The active metabolites of $\mathrm{t}$-Res, mainly Res-sulphate and Res-glucuronide, show higher plasma levels and are probably the only compounds that reach and accumulate in the tissues where they exert their protective effects [44]. Different strategies have been assessed to improve t-Res bioavailability [45]: (i) co-administration of t-Res metabolism inhibitors; (ii) use of naturally or chemically-synthesized t-Res analogs; and (iii) new t-Res delivery systems. t-Res bioavailability has also been improved using lipid solutions, microsomes or other vectorized forms [46]. $t$-Res oral dry powder forms are unable to raise t-Res plasma levels above $10 \mathrm{ng} / \mathrm{mL}$, except for one study claiming $52 \mathrm{ng} / \mathrm{mL}(0.23 \mu \mathrm{M})$. Our group recently showed that a single dose $(40 \mathrm{mg})$ of a soluble form of $\mathrm{t}$-Res, in a suitable lipid vehicle, elicits micromolar concentrations in the blood of human volunteers (up to $5.7 \mu \mathrm{M} ; 1400 \mathrm{ng} / \mathrm{mL}$ at $30 \mathrm{~min}$ ) [34]. t-Res was well absorbed and remained at biologically efficient blood levels for several hours, despite rapid metabolism and renal elimination. In contrast, the dry powder form was unable to elicit efficient blood levels at any time. Another benefit of the low doses used in the soluble form is the improved tolerance for t-Res. Previous dose-escalation studies in human volunteers showed that a one-gram dose of t-Res caused no significant adverse effects [38]. Higher doses were associated with infrequent minor gastrointestinal effects [47]. A study using $400 \mathrm{mg}$ reported minor adverse effects such as skin rash, headache and nasopharyngitis [48]. In our study, $\mathrm{t}$-Res was well tolerated and no toxicity was reported at the dose of $40 \mathrm{mg}$ despite the significant increase in t-Res plasma levels [34].

\subsection{Evidence of Joint Protective Properties}

\subsubsection{In Vitro Findings}

Even though most in vitro studies reported the use of $t-R e s$, one can assume that the cellular effects observed are rather those of active metabolites of $t$-Res than those of $t$-Res itself. Articular chondrocytes cultured in basal conditions are resistant to stimulation with active metabolites of $t$-Res at micromolar doses $(0.1$ to $10 \mu \mathrm{M})$ regardless of the molecular pathway considered. Several hypotheses can be brought up. Chondrocytes contain high levels of ceruleoplasmin, a copper-containing protein with a strong laccase activity [49]. Laccases are able to disrupt and inactivate active metabolites of t-Res propylene chain. Primary cultured rabbit chondrocytes also harbour particular AhR content and responsiveness to its ligands (Figure 2, Widerak M, Corvol MT and Savouret JF, personal data). In basal cultured conditions, AhR expression is weak and restricted to the cytoplasmic area of the chondrocytes (Figure 2A). In these conditions, $\mathrm{AhR}$ is not functional and chondrocytes do not respond to dioxin (2,3,7,8-tetrachlorodibenzo- $p$-dioxin, TCDD), the main ligand of AhR. Addition of interleukin (IL)-1 $\beta$ does not modify this compartmental localization. In contrast, AhR translocates to the nucleus in the presence of IL-1 $\beta$ plus TCDD (Figure 2B). In these conditions, increased AhR expression is observed under IL-1 $\beta$ stimulation upon AP1 activation, and is associated to increased expression of CYP1A1 and of inflammasome markers (Figure 2C).

The apparent inability of chondrocytes to respond to active metabolites of $\mathrm{t}$-Res in basal conditions in vitro could result from the low AhR basal level, which may be under its threshold of activation. Under inflammatory conditions, such as stimulation by IL-1 $\beta$, AhR content could reach such a threshold, allowing active metabolites of $t$-Res to inhibit AhR pathway (Figure 3). Consequently, active metabolites of t-Res could be more effective on chondrocytes in an inflammatory microenvironment. 

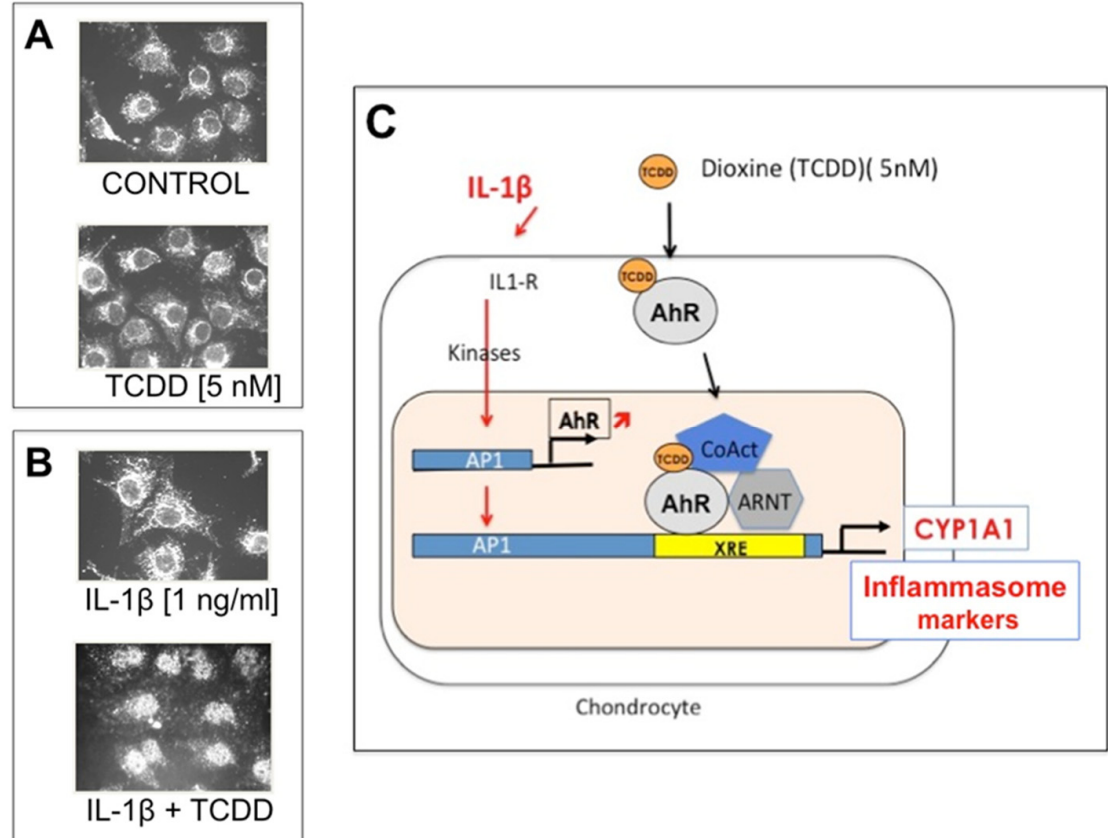

Figure 2. Aryl hydrocarbon and dioxin receptor (AhR)-a new target of IL-1 $\beta$ in chondrocytes. Rabbit chondrocytes were cultured in the absence (A) or in the presence (B) of IL-1 $\beta(5 \mathrm{nM})$ and 2,3,7,8-tetrachlorodibenzo- $p$-dioxin (TCDD). Ligand was added to the cells for $20 \mathrm{~h}$. AhR expression was studied by immunocytochemistry. (A) In the absence of IL- $1 \beta$, the AhR signal is restricted to the cytoplasmic area of chondrocytes. Addition of TCDD does not modify the AhR signal; (B) In contrast, in the presence of IL-1 $\beta$, addition of TCDD induces AhR translocation to the nucleus; (C) IL-1 $\beta$-increased expression of AhR over control values was shown to occur through AP1 activation and followed by robust expression of CYP1A1 (Widerak M, Corvol MT and Savouret JF, personal data).

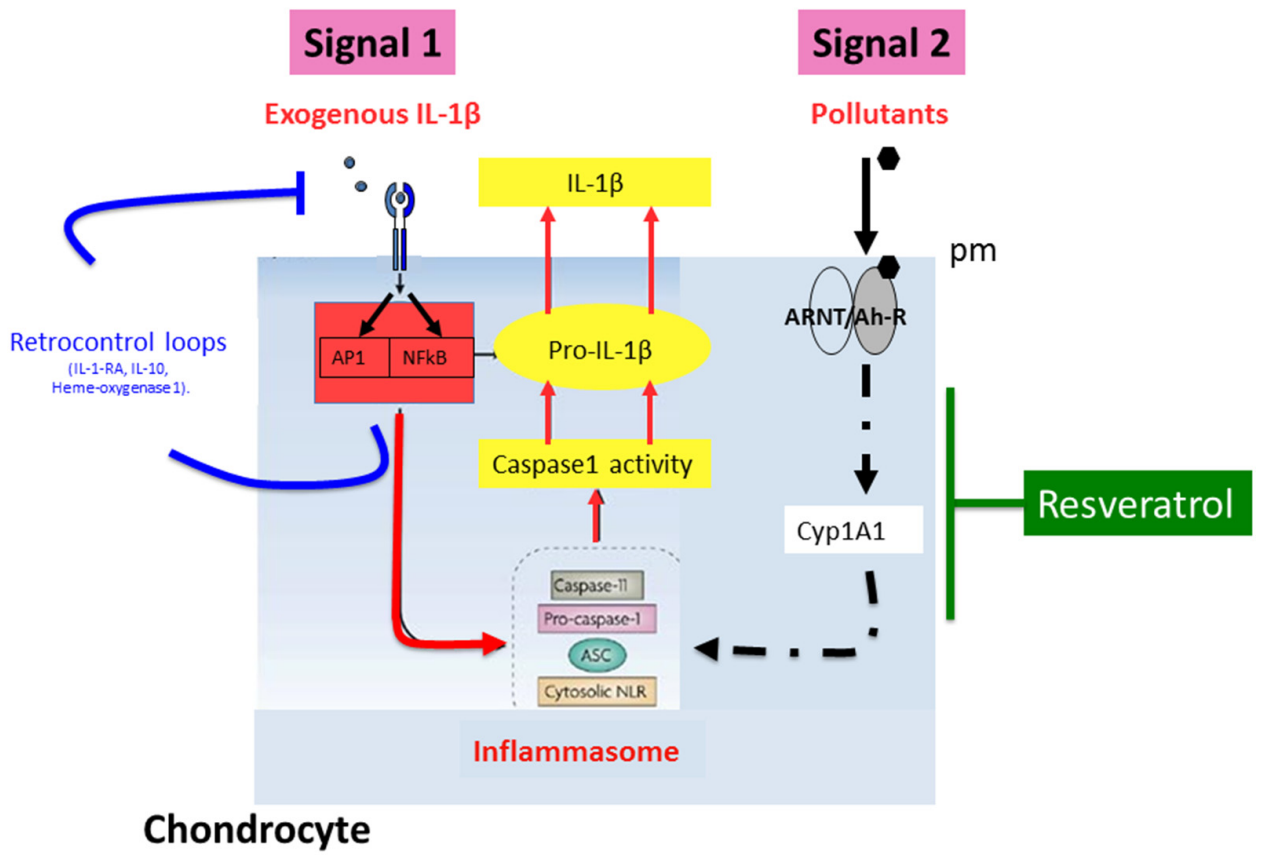

Figure 3. The anti-AhR effect of active metabolites of $t$-Res in chondrocytes could be more effective in the presence of pro-inflammatory cytokines. 
In addition, there is growing evidence of an effect of active metabolites of $t$-Res on pathological chondrocytes and synoviocytes. Inhibitory effects of active metabolites of t-Res on IL-1 $\beta$ and kinases modulation of matrix metalloproteinases (MMP)-1, -3 , and -13 expression in chondrocytes (endochondral cartilage and intervertebral disc) have been reported by several groups [50-54]. In some of these studies, active metabolites of t-Res doses ranged from 50 to $100 \mu \mathrm{M}$. Therefore, an indirect estrogenic effect via ER- $\alpha$ activation cannot be excluded [55-58]. Other groups have recently opened a new avenue in cartilage research by showing that synoviocytes, more than chondrocytes, might be the real target of active metabolites of $t$-Res anti-inflammatory activities. Active metabolites of $t$-Res inhibit IL-1 $\beta$, MMP-3 and phosphorylated Akt expression, either basal or Tumour Necrosis Factor (TNF) $\alpha$-induced, in a dose-dependent manner, between 6 and $50 \mu \mathrm{M}$ [59]. Caspase- 8 has also been reported to be a target of active metabolites of t-Res in synoviocytes at high doses $(50 \mu \mathrm{M})$ [60]. All the authors concluded that active metabolites of $t$-Res might have beneficial effects in preventing and treating rheumatoid arthritis (RA). Finally, resveratrol inhibits cell adhesion between monocytes and endothelial cells [61], a mechanism that might be extended to monocyte interactions with chondrocytes. The authors attributed this effect to tyrosine kinase inhibition, the other major effect of active metabolites of $\mathrm{t}$-Res with AhR activation; although the latter mechanism is also a potent pathway for ICAM-I expression [62].

\subsubsection{Preclinical Findings}

Although in vitro data strongly support a potent joint protection effect of resveratrol through modulation of inflammation, chondrolysis and angiogenesis, resveratrol health benefits still await in-depth investigation in animal models. Many reports use questionable modes of administration (wine, dry powder form) or erroneous targets, as once pointed out about platelet aggregation [3]. Only few papers have specifically investigated effects of $t$-Res in osteoarthritis (OA) or RA animal models.

In most of the studies in OA animal models, $t$-Res was administered by intra-articular injections. In a rabbit model of $\mathrm{OA}$, by unilateral anterior cruciate ligament transection, intra-articular injections of $\mathrm{t}$-Res hampered the progression of cartilage destruction and associated prod-degradative soluble factor production $[63,64]$. In Wang's study, intra-articular resveratrol was administered daily for two weeks at different dose regimen $(50,20$, and $10 \mu \mathrm{mol} / \mathrm{kg}$ ). In the groups treated with resveratrol, reduced cartilage lesions, apoptosis rate of chondrocytes and level of nitric oxide in the synovial fluid were observed in a dose-dependent fashion [64]. Consistently, Elmali and colleagues showed a reduction in cartilage destruction scores and loss of matrix proteoglycans in animals injected intra-articularly with $10 \mu \mathrm{mol} / \mathrm{kg}$ resveratrol for two weeks compared to DMSO injected animals. Scores of synovial inflammation were comparable between the two groups [63]. Most recently, in a mouse model of $\mathrm{OA}$, by destabilization of the medial meniscus, weekly intra-articular injection of resveratrol in the knee was associated with decreased cartilage and subchondral bone changes, along with unchanged type 2 collagen expression, and reduction in iNOS and MMP- 13 expressions, activation of Sirt- 1 and inhibition of Hypoxia Inducible Factor (HIF)-2 $\alpha$ [65]. The chondroprotective effect of oral resveratrol supplements on C57BL/6J mice fed with a high-fat diet during 12 weeks was assessed recently. In this study, osteoarthritic histological changes, cartilage degradation assessed by levels of $C$-telopeptide of type II collagen and apoptosis assessed by TUNEL staining were reduced in mice treated with low, intermediate or high doses of oral resveratrol [66]. To our knowledge, no study has reported pain outcomes or the influence of genetic inhibition of $\mathrm{AhR}$ in $\mathrm{AhR}-/$ - mice in these models.

Intriguingly, clinical epidemiological studies have suggested that alcohol intake, including red wine consumption, can be a protective factor in RA $[67,68]$. This has led to experimental studies assessing the role of red wine compounds such as resveratrol in this effect. t-Res alleviated cartilage destruction and inflammation in murine arthritis induced by collagen or lipopolysaccharides [69-72]. From a mechanistic point of view, Xuzhu and colleagues demonstrated, in the mouse collagen-induced arthritis model, that either prophylactic or therapeutic administration of resveratrol attenuated clinical arthritis parameters and bone erosions, and was associated with reduced serum levels of 
pro-inflammatory cytokines and collagen-specific IgG, reduced number of Th17 cells and of IL-17 in draining lymph nodes. These results suggest that the protective effects of resveratrol in this model may be mediated by the modulation of key cellular and humoral responses [72]. Most recently, Chen and colleagues, in the rat adjuvant arthritis model, reported that resveratrol $(10$ or $50 \mathrm{mg} / \mathrm{kg}$ ) significantly reduced paw swelling and arthritis scores, with suppression of synovial hyperplasia and inflammatory cell infiltrate, and reduction in the production of COX-2 and PGE2 [69].

Finally, treatment with oral t-Res has shown consistent osteoprotective properties in ovariectomy-induced osteoporosis in rats [73,74]. More recently, in eight-week-old obese diabetic mouse, oral t-Res administered for three weeks was associated to increased cortical area on bone histomorphometric analysis but decreased bone length [75].

\subsection{Interest of Resveratrol in Treating Joint Disorder-Related Symptoms in Humans}

Even though research on the effect of dietary polyphenols on human health has developed considerably and controversially in the past decade in such diverse fields as cancer, neurodegenerative and cardiovascular diseases, type 2 diabetes mellitus and other metabolic disorders [76], no clinical data are available to date regarding the efficacy of resveratrol in joint disorders, especially in OA or RA. Only one randomized, double-blinded, controlled trial assessed the effect of oral resveratrol on bone mineral density and bone alkaline phosphatase in obese men of two doses (1000 and $150 \mathrm{mg}$ ) compared to oral placebo administered for 16 weeks. In this study, the high dose of resveratrol was associated with an increase in bone alkaline phosphatase and lumbar spine trabecular volumetric bone mineral density suggesting a potential positive effect of oral resveratrol on bone formation [77]. This lack of trials in rheumatic disorders might be related to controversies associated with the relatively poor results from resveratrol treatment in other human conditions, particularly when compared to the financial investments involved [78,79]. In a recent meta-analysis of resveratrol efficacy in type 2 diabetes mellitus, Hausenblas and colleagues found that resveratrol supplementation was more effective than placebo/control for improving systolic blood pressure, hemoglobin A1c, and creatinine [80]. However, in a broader review of all clinical trials on resveratrol performed between 2010 and 2013, Cottart and colleagues failed to confirm clear beneficial effects of resveratrol [81]. The authors pointed out concerns in comparing results from different studies because of the differences in protocols used. Furthermore, as patient groups were often small, duration of the studies often short, and/or administered doses often low, this may explain, at least in part, the lack of consistent positive results. The controversy over resveratrol clinical positive effects has been recently further fueled by Semba and colleagues who conducted a nine-year prospective cohort study in a population-based sample of 783 community-dwelling men and women 65 years or older in Italy. Their results suggest that resveratrol levels achieved with a Western diet do not have a substantial influence on health status and all-cause mortality risk [82]. However, the measurement of resveratrol exposure by $24 \mathrm{~h}$-urinary resveratrol metabolites only at baseline remains a matter of debate as it may not reflect the real exposure to resveratrol during the nine-year follow-up [83]. In humans, it is probably impossible, only with diet, to reach a sufficient concentration of active metabolites of $\mathrm{t}$-Res at the targeted tissue. However, using food supplements that contain relatively high amounts of the compound, ranging from $55 \mathrm{mg}$ to more than $500 \mathrm{mg}$ per capsule, may allow reaching biologically active concentrations of the compound even considering the bioavailability factor [84].

Nevertheless, from in vitro and pre-clinical findings in the field of joint diseases, we believe that resveratrol administered with proper timing and sufficient biodisponibility, might be relevant as a complementary treatment for joint disorder-related symptoms in humans, in addition to conventional treatments.

\section{Conclusions}

For several years, based on in vitro and preclinical promising results, resveratrol has aroused keen interest because of its broad actions in almost every domain from metabolic disorders to 
cancer. In the field of rheumatic disorders, in vitro evidence clearly support anti-inflammatory, anti-catabolic, anti-apoptotic and anti-oxidative properties of t-Res in various articular cell types including chondrocytes and synoviocytes, along with immunomodulation properties on $\mathrm{T}$ and $\mathrm{B}$ lymphocytes. Consistently, resveratrol administered either intra-articularly or orally, has shown joint protective effects in pre-clinical models of OA and RA, mainly mediated by decreased production of pro-inflammatory and pro-degradative soluble factors, as well as modulation of cellular and humoral responses. In order to take the use of resveratrol to the next step of clinical trials in human joint diseases, new formulations of t-Res improving its biodisponibility and safety have been developed [34], and should allow for accurate assessment of its efficacy in OA and RA patients as an additional therapy to conventional treatment.

Acknowledgments: The authors declare that they have received no grants in support of their research work and no funds for covering the costs to publish in open access.

Author Contributions: All authors analyzed the data and wrote the paper.

Conflicts of Interest: The authors declare no conflict of interest.

\section{References}

1. Renaud, S.; Ruf, J.C. The french paradox: Vegetables or wine. Circulation 1994, 90, 3118-3119. [CrossRef] [PubMed]

2. Constant, J. Alcohol, ischemic heart disease, and the french paradox. Coron. Artery Dis. 1997, 8, 645-649. [CrossRef] [PubMed]

3. Soleas, G.J.; Diamandis, E.P.; Goldberg, D.M. Resveratrol: A molecule whose time has come? And gone? Clin. Biochem. 1997, 30, 91-113. [CrossRef]

4. Fremont, L. Biological effects of resveratrol. Life Sci. 2000, 66, 663-673. [CrossRef]

5. Jang, M.; Cai, L.; Udeani, G.O.; Slowing, K.V.; Thomas, C.F.; Beecher, C.W.; Fong, H.H.; Farnsworth, N.R.; Kinghorn, A.D.; Mehta, R.G.; et al. Cancer chemopreventive activity of resveratrol, a natural product derived from grapes. Science 1997, 275, 218-220. [CrossRef] [PubMed]

6. Udenigwe, C.C.; Ramprasath, V.R.; Aluko, R.E.; Jones, P.J. Potential of resveratrol in anticancer and anti-inflammatory therapy. Nutr. Rev. 2008, 66, 445-454. [CrossRef] [PubMed]

7. Fulda, S.; Galluzzi, L.; Kroemer, G. Targeting mitochondria for cancer therapy. Nat. Rev. Drug Discov. 2010, 9 , 447-464. [CrossRef] [PubMed]

8. Bishayee, A.; Waghray, A.; Barnes, K.F.; Mbimba, T.; Bhatia, D.; Chatterjee, M.; Darvesh, A.S. Suppression of the inflammatory cascade is implicated in resveratrol chemoprevention of experimental hepatocarcinogenesis. Pharm. Res. 2010, 27, 1080-1091. [CrossRef] [PubMed]

9. Frojdo, S.; Durand, C.; Pirola, L. Metabolic effects of resveratrol in mammals-A link between improved insulin action and aging. Curr. Aging Sci. 2008, 1, 145-151. [CrossRef] [PubMed]

10. Hung, C.F.; Lin, Y.K.; Huang, Z.R.; Fang, J.Y. Delivery of resveratrol, a red wine polyphenol, from solutions and hydrogels via the skin. Biol. Pharm. Bull. 2008, 31, 955-962. [CrossRef] [PubMed]

11. Das, S.; Das, D.K. Anti-inflammatory responses of resveratrol. Inflamm. Allergy Drug Targets 2007, 6, 168-173. [CrossRef] [PubMed]

12. Savouret, J.F.; Berdeaux, A.; Casper, R.F. The aryl hydrocarbon receptor and its xenobiotic ligands: A fundamental trigger for cardiovascular diseases. Nutr. Metab. Cardiovasc. Dis. 2003, 13, 104-113. [CrossRef]

13. Subbaramaiah, K.; Chung, W.J.; Michaluart, P.; Telang, N.; Tanabe, T.; Inoue, H.; Jang, M.; Pezzuto, J.M.; Dannenberg, A.J. Resveratrol inhibits cyclooxygenase-2 transcription and activity in phorbol ester-treated human mammary epithelial cells. J. Biol. Chem. 1998, 273, 21875-21882. [CrossRef] [PubMed]

14. Casper, R.F.; Quesne, M.; Rogers, I.M.; Shirota, T.; Jolivet, A.; Milgrom, E.; Savouret, J.F. Resveratrol has antagonist activity on the aryl hydrocarbon receptor: Implications for prevention of dioxin toxicity. Mol. Pharmacol. 1999, 56, 784-790. [PubMed]

15. Lopez-Lluch, G.; Cruz-Calvo, S.S.; Navas, P. Resveratrol in cancer: Cellular and mitochondrial consequences of proton transport inhibition. Curr. Pharm. Design 2012, 18, 1338-1344. [CrossRef] 
16. Bowers, J.L.; Tyulmenkov, V.V.; Jernigan, S.C.; Klinge, C.M. Resveratrol acts as a mixed agonist/antagonist for estrogen receptors $\alpha$ and $\beta$. Endocrinology 2000, 141, 3657-3667. [CrossRef] [PubMed]

17. De Medina, P.; Casper, R.; Savouret, J.F.; Poirot, M. Synthesis and biological properties of new stilbene derivatives of resveratrol as new selective aryl hydrocarbon modulators. J. Med. Chem. 2005, 48, 287-291. [CrossRef] [PubMed]

18. Gao, S.; Liu, G.Z.; Wang, Z. Modulation of androgen receptor-dependent transcription by resveratrol and genistein in prostate cancer cells. Prostate 2004, 59, 214-225. [CrossRef] [PubMed]

19. Holmes-McNary, M.; Baldwin, A.S., Jr. Chemopreventive properties of trans-resveratrol are associated with inhibition of activation of the ikb kinase. Cancer Res. 2000, 60, 3477-3483. [PubMed]

20. Kundu, J.K.; Chun, K.S.; Kim, S.O.; Surh, Y.J. Resveratrol inhibits phorbol ester-induced cyclooxygenase-2 expression in mouse skin: Mapks and AP-1 as potential molecular targets. BioFactors 2004, 21, 33-39. [CrossRef] [PubMed]

21. Yu, R.; Hebbar, V.; Kim, D.W.; Mandlekar, S.; Pezzuto, J.M.; Kong, A.N. Resveratrol inhibits phorbol ester and UV-induced activator protein 1 activation by interfering with mitogen-activated protein kinase pathways. Mol. Pharmacol. 2001, 60, 217-224. [PubMed]

22. Savouret, J.F.; Quesne, M. Resveratrol and cancer: A review. Biomed. Pharm. 2002, 56, 84-87. [CrossRef]

23. Shakibaei, M.; Harikumar, K.B.; Aggarwal, B.B. Resveratrol addiction: To die or not to die. Mol. Nutr. Food Res. 2009, 53, 115-128. [CrossRef] [PubMed]

24. She, Q.B.; Ma, W.Y.; Wang, M.; Kaji, A.; Ho, C.T.; Dong, Z. Inhibition of cell transformation by resveratrol and its derivatives: Differential effects and mechanisms involved. Oncogene 2003, 22, 2143-2150. [CrossRef] [PubMed]

25. Zhu, C.; Xie, Q.; Zhao, B. The role of ahr in autoimmune regulation and its potential as a therapeutic target against CD4 T cell mediated inflammatory disorder. Int. J. Mol. Sci. 2014, 15, 10116-10135. [CrossRef] [PubMed]

26. Lin, T.M.; Ko, K.; Moore, R.W.; Buchanan, D.L.; Cooke, P.S.; Peterson, R.E. Role of the aryl hydrocarbon receptor in the development of control and 2,3,7,8-tetrachlorodibenzo-p-dioxin-exposed male mice. J. Toxicol. Environ. Health A 2001, 64, 327-342. [CrossRef] [PubMed]

27. Veldhoen, M.; Hirota, K.; Westendorf, A.M.; Buer, J.; Dumoutier, L.; Renauld, J.C.; Stockinger, B. The aryl hydrocarbon receptor links th17-cell-mediated autoimmunity to environmental toxins. Nature 2008, 453, 106-109. [CrossRef] [PubMed]

28. Esser, C. The immune phenotype of AHR null mouse mutants: Not a simple mirror of xenobiotic receptor over-activation. Biochem. Pharmacol. 2009, 77, 597-607. [CrossRef] [PubMed]

29. Petro, T.M. Regulatory role of resveratrol on TH17 in autoimmune disease. Int. Immunopharmacol. 2011, 11, 310-318. [CrossRef] [PubMed]

30. Sulaiman, M.; Matta, M.J.; Sunderesan, N.R.; Gupta, M.P.; Periasamy, M.; Gupta, M. Resveratrol, an activator of sirt1, upregulates sarcoplasmic calcium atpase and improves cardiac function in diabetic cardiomyopathy. Am. J. Physiol. Heart Circ. Physiol. 2010, 298, H833-843. [CrossRef] [PubMed]

31. Savouret, J.F.; Antenos, M.; Quesne, M.; Xu, J.; Milgrom, E.; Casper, R.F. 7-ketocholesterol is an endogenous modulator for the arylhydrocarbon receptor. J. Biol. Chem. 2001, 276, 3054-3059. [CrossRef] [PubMed]

32. Baur, J.A.; Pearson, K.J.; Price, N.L.; Jamieson, H.A.; Lerin, C.; Kalra, A.; Prabhu, V.V.; Allard, J.S.; Lopez-Lluch, G.; Lewis, K.; et al. Resveratrol improves health and survival of mice on a high-calorie diet. Nature 2006, 444, 337-342. [CrossRef] [PubMed]

33. Park, G.J.; Kim, Y.S.; Kang, K.L.; Bae, S.J.; Baek, H.S.; Auh, Q.S.; Chun, Y.H.; Park, B.H.; Kim, E.C. Effects of sirtuin 1 activation on nicotine and lipopolysaccharide-induced cytotoxicity and inflammatory cytokine production in human gingival fibroblasts. J. Periodontal Res. 2013, 48, 483-492. [CrossRef] [PubMed]

34. Amiot, M.J.; Romier, B.; Dao, T.M.; Fanciullino, R.; Ciccolini, J.; Burcelin, R.; Pechere, L.; Emond, C.; Savouret, J.F.; Seree, E. Optimization of trans-resveratrol bioavailability for human therapy. Biochimie 2013, 95, 1233-1238. [CrossRef] [PubMed]

35. Hsieh, Y.C.; Yang, S.; Choudhry, M.A.; Yu, H.P.; Rue, L.W., 3rd; Bland, K.I.; Chaudry, I.H. Pgc-1 upregulation via estrogen receptors: A common mechanism of salutary effects of estrogen and flutamide on heart function after trauma-hemorrhage. Am. J. Physiol. 2005, 289, H2665-H2672. [CrossRef] [PubMed] 
36. Rogers, N.H.; Witczak, C.A.; Hirshman, M.F.; Goodyear, L.J.; Greenberg, A.S. Estradiol stimulates AKT, amp-activated protein kinase (AMPK) and TBC1D1/4, but not glucose uptake in rat soleus. Biochem. Biophys. Res. Commun. 2009, 382, 646-650. [CrossRef] [PubMed]

37. Garber, K. A mid-life crisis for aging theory. Nat. Biotechnol. 2008, 26, 371-374. [CrossRef] [PubMed]

38. Cottart, C.H.; Nivet-Antoine, V.; Laguillier-Morizot, C.; Beaudeux, J.L. Resveratrol bioavailability and toxicity in humans. Mol. Nutr. Food Res. 2010, 54, 7-16. [CrossRef] [PubMed]

39. Juan, M.E.; Alfaras, I.; Planas, J.M. Determination of dihydroresveratrol in rat plasma by HPLC. J. Agric. Food Chem. 2010, 58, 7472-7475. [CrossRef] [PubMed]

40. Walle, T.; Hsieh, F.; DeLegge, M.H.; Oatis, J.E., Jr.; Walle, U.K. High absorption but very low bioavailability of oral resveratrol in humans. Drug Metab. Dispos. 2004, 32, 1377-1382. [CrossRef] [PubMed]

41. Wenzel, E.; Somoza, V. Metabolism and bioavailability of trans-resveratrol. Mol. Nutr. Food Res. 2005, 49, 472-481. [CrossRef] [PubMed]

42. Saiko, P.; Szakmary, A.; Jaeger, W.; Szekeres, T. Resveratrol and its analogs: Defense against cancer, coronary disease and neurodegenerative maladies or just a fad? Mutat. Res. 2008, 658, 68-94. [CrossRef] [PubMed]

43. Zhuang, H.; Kim, Y.S.; Koehler, R.C.; Dore, S. Potential mechanism by which resveratrol, a red wine constituent, protects neurons. Ann. N. Y. Acad. Sci. 2003, 993, 276-286. [CrossRef] [PubMed]

44. Bresciani, L.; Calani, L.; Bocchi, L.; Delucchi, F.; Savi, M.; Ray, S.; Brighenti, F.; Stilli, D.; del Rio, D. Bioaccumulation of resveratrol metabolites in myocardial tissue is dose-time dependent and related to cardiac hemodynamics in diabetic rats. Nutr. Metab. Cardiovasc. Dis. 2014, 24, 408-415. [CrossRef] [PubMed]

45. Amri, A.; Chaumeil, J.C.; Sfar, S.; Charrueau, C. Administration of resveratrol: What formulation solutions to bioavailability limitations? J. Control Release 2012, 158, 182-193. [CrossRef] [PubMed]

46. Santos, A.C.; Veiga, F.; Ribeiro, A.J. New delivery systems to improve the bioavailability of resveratrol. Expert Opin. Drug Deliv. 2011, 8, 973-990. [CrossRef] [PubMed]

47. Brown, V.A.; Patel, K.R.; Viskaduraki, M.; Crowell, J.A.; Perloff, M.; Booth, T.D.; Vasilinin, G.; Sen, A.; Schinas, A.M.; Piccirilli, G.; et al. Repeat dose study of the cancer chemopreventive agent resveratrol in healthy volunteers: Safety, pharmacokinetics, and effect on the insulin-like growth factor axis. Cancer Res. 2010, 70, 9003-9011. [CrossRef] [PubMed]

48. Almeida, L.; Vaz-da-Silva, M.; Falcao, A.; Soares, E.; Costa, R.; Loureiro, A.I.; Fernandes-Lopes, C.; Rocha, J.F.; Nunes, T.; Wright, L.; et al. Pharmacokinetic and safety profile of trans-resveratrol in a rising multiple-dose study in healthy volunteers. Mol. Nutr. Food Res. 2009, 53 (Suppl. S1), S7-S15. [CrossRef] [PubMed]

49. Yang, F.M.; Friedrichs, W.E.; Cupples, R.L.; Bonifacio, M.J.; Sanford, J.A.; Horton, W.A.; Bowman, B.H. Human ceruloplasmin: Tissue-specific expression of transcripts produced by alternative splicing. J. Biol. Chem. 1990, 265, 10780-10785. [PubMed]

50. Dave, M.; Attur, M.; Palmer, G.; Al-Mussawir, H.E.; Kennish, L.; Patel, J.; Abramson, S.B. The antioxidant resveratrol protects against chondrocyte apoptosis via effects on mitochondrial polarization and atp production. Arthritis Rheum. 2008, 58, 2786-2797. [CrossRef] [PubMed]

51. Li, X.; Phillips, F.M.; An, H.S.; Ellman, M.; Thonar, E.J.; Wu, W.; Park, D.; Im, H.J. The action of resveratrol, a phytoestrogen found in grapes, on the intervertebral disc. Spine 2008, 33, 2586-2595. [CrossRef] [PubMed]

52. Malemud, C.J. Inhibitors of stress-activated protein/mitogen-activated protein kinase pathways. Curr. Opin. Pharmacol. 2007, 7, 339-343. [CrossRef] [PubMed]

53. Mengshol, J.A.; Vincenti, M.P.; Coon, C.I.; Barchowsky, A.; Brinckerhoff, C.E. Interleukin-1 induction of collagenase 3 (matrix metalloproteinase 13) gene expression in chondrocytes requires p38, c-Jun N-terminal kinase, and nuclear factor kb: Differential regulation of collagenase 1 and collagenase 3. Arthritis Rheum. 2000, 43, 801-811. [CrossRef]

54. Shakibaei, M.; Mobasheri, A.; Buhrmann, C. Curcumin synergizes with resveratrol to stimulate the MAPK signaling pathway in human articular chondrocytes in vitro. Genes Nutr. 2011, 6, 171-179. [CrossRef] [PubMed]

55. Csaki, C.; Mobasheri, A.; Shakibaei, M. Synergistic chondroprotective effects of curcumin and resveratrol in human articular chondrocytes: Inhibition of IL-1 $\beta$-induced NF-kb-mediated inflammation and apoptosis. Arthritis Res. Ther. 2009, 11, R165. [CrossRef] [PubMed]

56. Lei, M.; Liu, S.Q.; Liu, Y.L. Resveratrol protects bone marrow mesenchymal stem cell derived chondrocytes cultured on chitosan-gelatin scaffolds from the inhibitory effect of interleukin-1ß. Acta Pharmacol. Sin. 2008, 29, 1350-1356. [CrossRef] [PubMed] 
57. Liu, F.C.; Hung, L.F.; Wu, W.L.; Chang, D.M.; Huang, C.Y.; Lai, J.H.; Ho, L.J. Chondroprotective effects and mechanisms of resveratrol in advanced glycation end products-stimulated chondrocytes. Arthritis Res. Ther. 2010, 12, R167. [CrossRef] [PubMed]

58. Shakibaei, M.; Csaki, C.; Nebrich, S.; Mobasheri, A. Resveratrol suppresses interleukin-1 $\beta$-induced inflammatory signaling and apoptosis in human articular chondrocytes: Potential for use as a novel nutraceutical for the treatment of osteoarthritis. Biochem. Pharmacol. 2008, 76, 1426-1439. [CrossRef] [PubMed]

59. Tian, J.; Chen, J.W.; Gao, J.S.; Li, L.; Xie, X. Resveratrol inhibits TNF- $\alpha$-induced IL-1 $\beta$, MMP-3 production in human rheumatoid arthritis fibroblast-like synoviocytes via modulation of pi3kinase/AKT pathway. Rheumatol. Int. 2013, 33, 1829-1835. [CrossRef] [PubMed]

60. Byun, H.S.; Song, J.K.; Kim, Y.R.; Piao, L.; Won, M.; Park, K.A.; Choi, B.L.; Lee, H.; Hong, J.H.; Park, J.; et al. Caspase-8 has an essential role in resveratrol-induced apoptosis of rheumatoid fibroblast-like synoviocytes. Rheumatology 2008, 47, 301-308. [CrossRef] [PubMed]

61. Ferrero, M.E.; Bertelli, A.E.; Fulgenzi, A.; Pellegatta, F.; Corsi, M.M.; Bonfrate, M.; Ferrara, F.; de Caterina, R.; Giovannini, L.; Bertelli, A. Activity in vitro of resveratrol on granulocyte and monocyte adhesion to endothelium. Am. J. Clin. Nutr. 1998, 68, 1208-1214. [PubMed]

62. Vorderstrasse, B.A.; Steppan, L.B.; Silverstone, A.E.; Kerkvliet, N.I. Aryl hydrocarbon receptor-deficient mice generate normal immune responses to model antigens and are resistant to tcdd-induced immune suppression. Toxicol. Appl. Pharmacol. 2001, 171, 157-164. [CrossRef] [PubMed]

63. Elmali, N.; Esenkaya, I.; Harma, A.; Ertem, K.; Turkoz, Y.; Mizrak, B. Effect of resveratrol in experimental osteoarthritis in rabbits. Inflamm. Res. 2005, 54, 158-162. [CrossRef] [PubMed]

64. Wang, J.; Gao, J.S.; Chen, J.W.; Li, F.; Tian, J. Effect of resveratrol on cartilage protection and apoptosis inhibition in experimental osteoarthritis of rabbit. Rheumatol. Int. 2012, 32, 1541-1548. [CrossRef] [PubMed]

65. Li, W.; Cai, L.; Zhang, Y.; Cui, L.; Shen, G. Intra-articular resveratrol injection prevents osteoarthritis progression in a mouse model by activating SIRT1 and thereby silencing HIF-2 $\alpha$. J. Orthop. Res. 2015, 33, 1061-1070. [CrossRef] [PubMed]

66. Gu, H.; Li, K.; Li, X.; Yu, X.; Wang, W.; Ding, L.; Liu, L. Oral resveratrol prevents osteoarthritis progression in C57BL/6J mice fed a high-fat diet. Nutrients 2016, 8, 233. [CrossRef] [PubMed]

67. Lu, B.; Solomon, D.H.; Costenbader, K.H.; Keenan, B.T.; Chibnik, L.B.; Karlson, E.W. Alcohol consumption and markers of inflammation in women with preclinical rheumatoid arthritis. Arthritis Rheum. 2010, 62, 3554-3559. [CrossRef] [PubMed]

68. Nissen, M.J.; Gabay, C.; Scherer, A.; Finckh, A.; Swiss Clinical Quality Management Project in Rheumatoid Arthritis. The effect of alcohol on radiographic progression in rheumatoid arthritis. Arthritis Rheum. 2010, 62, 1265-1272. [CrossRef] [PubMed]

69. Chen, X.; Lu, J.; An, M.; Ma, Z.; Zong, H.; Yang, J. Anti-inflammatory effect of resveratrol on adjuvant arthritis rats with abnormal immunological function via the reduction of cyclooxygenase-2 and prostaglandin E2. Mol. Med. Rep. 2014, 9, 2592-2598. [CrossRef] [PubMed]

70. Elmali, N.; Baysal, O.; Harma, A.; Esenkaya, I.; Mizrak, B. Effects of resveratrol in inflammatory arthritis. Inflammation 2007, 30, 1-6. [CrossRef] [PubMed]

71. Wang, K.T.; Chen, L.G.; Tseng, S.H.; Huang, J.S.; Hsieh, M.S.; Wang, C.C. Anti-inflammatory effects of resveratrol and oligostilbenes from vitis thunbergii var. Taiwaniana against lipopolysaccharide-induced arthritis. J. Agric. Food Chem. 2011, 59, 3649-3656. [CrossRef] [PubMed]

72. Xuzhu, G.; Komai-Koma, M.; Leung, B.P.; Howe, H.S.; McSharry, C.; McInnes, I.B.; Xu, D. Resveratrol modulates murine collagen-induced arthritis by inhibiting TH17 and B-cell function. Ann. Rheum. Dis. 2012, 71, 129-135. [CrossRef] [PubMed]

73. Lin, Q.; Huang, Y.M.; Xiao, B.X.; Ren, G.F. Effects of resveratrol on bone mineral density in ovarectomized rats. Int. J. Biomed. Sci. 2005, 1, 76-81. [PubMed]

74. Mizutani, K.; Ikeda, K.; Kawai, Y.; Yamori, Y. Resveratrol attenuates ovariectomy-induced hypertension and bone loss in stroke-prone spontaneously hypertensive rats. J. Nutr. Sci. Vitaminol. 2000, 46, 78-83. [CrossRef] [PubMed]

75. Cooley, J.; Broderick, T.L.; Al-Nakkash, L.; Plochocki, J.H. Effects of resveratrol treatment on bone and cartilage in obese diabetic mice. J. Diabetes Metab. Disord. 2015, 14, 10. [CrossRef] [PubMed] 
76. Smoliga, J.M.; Baur, J.A.; Hausenblas, H.A. Resveratrol and health-A comprehensive review of human clinical trials. Mol. Nutr. Food Res. 2011, 55, 1129-1141. [CrossRef] [PubMed]

77. Ornstrup, M.J.; Harslof, T.; Kjaer, T.N.; Langdahl, B.L.; Pedersen, S.B. Resveratrol increases bone mineral density and bone alkaline phosphatase in obese men: A randomized placebo-controlled trial. J. Clin. Endocrinol. Metab. 2014, 99, 4720-4729. [CrossRef] [PubMed]

78. Cottart, C.H.; Nivet-Antoine, V.; Beaudeux, J.L. Is resveratrol an imposter? Mol. Nutr. Food Res. $2015,59,7$. [CrossRef] [PubMed]

79. Visioli, F. The resveratrol fiasco. Pharmacol. Res. 2014, 90, 87. [CrossRef] [PubMed]

80. Hausenblas, H.A.; Schoulda, J.A.; Smoliga, J.M. Resveratrol treatment as an adjunct to pharmacological management in type 2 diabetes mellitus-Systematic review and meta-analysis. Mol. Nutr. Food Res. 2015, 59, 147-159. [CrossRef] [PubMed]

81. Cottart, C.H.; Nivet-Antoine, V.; Beaudeux, J.L. Review of recent data on the metabolism, biological effects, and toxicity of resveratrol in humans. Mol. Nutr. Food Res. 2014, 58, 7-21. [CrossRef] [PubMed]

82. Semba, R.D.; Ferrucci, L.; Bartali, B.; Urpi-Sarda, M.; Zamora-Ros, R.; Sun, K.; Cherubini, A.; Bandinelli, S.; Andres-Lacueva, C. Resveratrol levels and all-cause mortality in older community-dwelling adults. JAMA Intern. Med. 2014, 174, 1077-1084. [CrossRef] [PubMed]

83. Brown, K.; Rufini, A.; Gescher, A. Do not throw out the resveratrol with the bath water. JAMA Intern. Med. 2015, 175, 140-141. [CrossRef] [PubMed]

84. Rossi, D.; Guerrini, A.; Bruni, R.; Brognara, E.; Borgatti, M.; Gambari, R.; Maietti, S.; Sacchetti, G. Trans-resveratrol in nutraceuticals: Issues in retail quality and effectiveness. Molecules 2012, 17, 12393-12405. [CrossRef] [PubMed]

(C) 2017 by the authors; licensee MDPI, Basel, Switzerland. This article is an open access article distributed under the terms and conditions of the Creative Commons Attribution (CC-BY) license (http://creativecommons.org/licenses/by/4.0/). 